\title{
PELATIHAN PEMBUATAN HAND SANITIZER (HANZER) MENGGUNAKAN EKSTRAK DAUN HALBAN (Vitex pinnata linn) DAN LIDAH BUAYA (Aloe vera) DALAM UPAYA PENCEGAHAN PENYEBARAN COVID-19 DI DESA KOTALINTANG KABUPATEN ACEH TAMIANG
}

\author{
Rahmatul Fajri' ${ }^{1}$, Halimatussakdiah ${ }^{1}$, Beni Al Fajar², Jofrishal ${ }^{3}$ \\ 1MIPA Kimia, Fakultas Teknik Universitas Samudra \\ 2MIPA Biologi, Fakultas Teknik Universitas Samudra \\ 3FKIP Kimia, Fakultas Keguruan dan Ilmu pendidikan Universitas Samudra \\ suryapijar@yahoo.com
}

\begin{abstract}
Kota Lintang Village is one of the villages in Kota Kuala Simpang Sub-District, Aceh Tamiang District, with 7054 people. Kota Lintang Village is one of the regions directly adjacent to North Sumatra Province, so it is the main trade route in and out. Therefore Kota Lintang Village can become the main route for the spread of the Covid-19 virus in Aceh. The emergence of the coronavirus diseases or Covid-19 in the past six months has made people panic and caused most people to buy antiseptic fluids thought to kill germs or viruses. This case makes antiseptic liquids scarce on the market. One form of antiseptic fluids on the market is hand sanitizer. Its scarcity in the market has triggered the community service team (PKM) of Universitas Samudra to conduct training in making hand sanitizers based on natural ingredients to inhibit and prevent coronavirus infection for residents of Kota Lintang Village, Aceh Tamiang District. The natural ingredients used are halban (Vitex pinnata Linn), and aloe vera leaves extracts found around the village as an antimicrobial and softener in hand sanitizers. Implementing the activities includes three main phases, namely socialization, training, and assistance to monitor and evaluate the progress of the results of activities for the sustainability of the PKM program in this village. The result of this PKM activity is that the target partners can make their hand sanitizers. Through this educational activity, it is hoped that it will increase public awareness of the importance of maintaining hand hygiene and improving community knowledge and skills on making hand sanitizers with natural ingredients.
\end{abstract}

Keywords: Kota Lintang, Hand sanitizer, Natural materials.

\begin{abstract}
Abstrak
Desa Kota Lintang merupakan salah satu desa yang ada di kecamatan Kota Kuala Simpang kabupaten Aceh Tamiang dengan jumlah penduduk mencapai 7054 jiwa. Desa Kota Lintang adalah salah satu daerah yang berbatasan langsung dengan Provinsi Sumatera Utara, sehingga menjadi jalur utama keluar masuknya perdagangan. Oleh karena itu Desa Kota Lintang berpotensi menjadi jalur utama penyebaran virus Covid-19 di Aceh. Kemunculan penyakit virus corona atau Covid-19 selama enam bulan belakangan ini membuat masyarakat panik, dan menyebabkan sebagian besar masyarakat memborong cairan antiseptik yang dianggap dapat membunuh kuman ataupun virus. Hal tersebut menjadikan cairan antiseptik menjadi langka di pasaran. Salah satu bentuk cairan antiseptik yang beredar di pasaran adalah hand sanitizer. Kelangkaannya di pasaran memicu tim pengabdian kepada masyarakat (PKM) Universitas Samudra melakukan pelatihan pembuatan hand sanitizer berbasis bahan alami untuk menghambat dan mencegah infeksi virus corona bagi warga desa Kota Lintang kabupaten Aceh Tamiang. Bahan alami yang digunakan adalah ekstrak daun halban (Vitex pinnata Linn) dan lidah buaya (Aloe vera) yang terdapat di sekitar desa sebagai antimikroba dan pelembut dalam hand sanitizer. Metode pelaksanaan kegiatan meliputi tiga tahapan utama, yaitu sosialisasi, pelatihan, dan pendampingan untuk memonitoring dan mengevaluasi perkembangan hasil kegiatan untuk keberlanjutan program PKM di desa tersebut. Hasil kegiatan PKM ini adalah mitra sasaran memiliki keterampilan dalam membuat hand sanitizer sendiri. Melalui kegiatan edukasi ini diharapkan akan meningkatkan kesadaran masyarakat akan pentingnya
\end{abstract}


Rahmatul Fajri, dkk. Pelatihan Pembuatan Hand Sanitizer (Hanzer) Menggunakan ...

menjaga kebersihan tangan serta meningkatkan pengetahuan dan keterampilan masyarakat tentang cara membuat hand sanitizer dengan bahan-bahan alami.

Kata kunci: Kota Lintang, Hand sanitizer, Bahan alami.

\section{PENDAHULUAN}

Kabupaten Aceh Tamiang merupakan kabupaten yang berbatasan langsung dengan Sumatra Utara, sehingga memiliki akses yang mudah untuk keluar masuknya para pendatang dari daerah lain. Kotalintang merupakan salah satu desa yang ada di kecamatan Kota Kuala Simpang kabupaten Aceh Tamiang dengan jumlah penduduk mencapai 7054 jiwa (Media Aceh, 2014).

Masyarakat Kota Lintang pada umunya mempunyai tingkat pendidikan yang memadai, yaitu $70 \%$ dari masyarakat setempat telah menyelesaikan pendidikan pada jenjang Sekolah Menengah Atas (SMA), bahkan sebagian dari mereka sedang melanjutkan pendidikan ke bangku perkuliahan. Meskipun memadainya pendidikan yang diperoleh namun tidak sejalan dengan perilaku kehidupan dalam bermasyarakat. Hal tersebut dapat dilihat dari kurangnya kesadaran masyarakat dalam menjaga kebersihan lingkungan sekitar dan kesehatan. Misalnya, masih banyak masyarakat setempat yang kurang peduli terhadap fasilitas sanitasi yang memadai di tempat tinggalnya. Selain itu, pola atau higienitas yang baik seperti sikat gigi dan cuci tangan juga masih belum dilakukan seluruh masyarakat Kotalintang. Minimnya kesadaran masyarakat terhadap kebersihan berpengaruh besar terhadap kesehatan. Penyakit infeksi saluran pernafasan akut (ISPA) dan diare adalah dua penyakit utama yang disebabkan oleh lingkungan yang kurang bersih (Dwi, 2013). Bukan hanya itu, persebaran virus lainnya juga bisa terjadi dengan cepat. Salah satunya adalah virus Corona.

Virus Corona atau lebih dikenal dengan Covid-19 merupakan salah satu jenis virus baru yang sedang mewabah di seluruh dunia termasuk Indonesia. Virus ini mampu menginfeksi sistem pernafasan. Pada banyak kasus, virus ini hanya menyebabkan infeksi pernafasan ringan, namun pada banyak kasus lainnya virus ini bisa menyebabkan infeksi pernafasan berat, seperti pneumonia. Virus ini menyebar dengan sangat cepat. Seperti melalui percikan air liur pengidap (bantuk dan bersin), menyentuh tangan atau wajah orang yang terinfeksi, menyentuh mata, hidung, atau mulut setelah memegang barang yang terkena percikan air liur pengidap (Yuliana, 2020).

Sampai saat ini, Dinas kesehatan belum menetapkan vaksin yang cocok untuk digunakan dalam mencegah infeksi virus Corona atau Covid-19. Oleh sebab itu, cara pencegahan yang baik adalah dengan menghindari faktorfaktor yang bisa terinfeksi virus ini, antara lain menerapkan physical distancing yaitu menjaga jarak minimal satu meter dari orang lain, menggunakan masker saat beraktivitas di tempat umum dan rutin mencuci tangah mengunakan air dan sabun atau hand sanitizer yang mengandung alkohol minimal $60 \%$ terutama setelah berkativitas di luar rumah atau di tempat umum. Pemerintah juga telah melakukan berbagai upaya untuk menghambar penyebaran virus Corona tersebut (Direktorat Jenderal Pencegahan dan Pengendalian Penyakit, 2020). 
Saat ini, pemerintah Indonesia dan Aceh khususnya sedang mengampanyekan gerakan mencuci tangan guna mencegah penyebaran virus Corona, mencuci tangan dengan sabun dan air mengalir adalah cara yang paling efektif untuk mencegah berkembangnya bakteri, kuman dan juga virus, termasuk virus Corona (Dinas kesehatan Pemerintah Provinsi Aceh, 2020). Akan tetapi dengan aktivitas dan kesibukan masyarakat setempat yang beragam dan pendapatan ekonomi yang rendah mengharuskan masyarakat untuk tetap keluar rumah, meskipun seruan dari pemerintah melarang untuk beraktivitas di luar rumah. Kesibukan tersebut menjadi kendala bagi masyarakat untuk selalu mencuci tangan, sehingga waktu untuk mencuci tangan menjadi sebuah masalah. Ketika mereka berada di tempat umum maka akan sulit menemukan air dan sabun untuk menjaga kebersihan dan kesehatan tangan. Alternatif lain yang dapat dilakukan yaitu menggunakan hand sanitizer untuk menjaga kebersihan dan kesehatan tangan.

Hand sanitizer adalah cairan pembersih tangan yang digunakan sebagai alternatif untuk mencuci tangan selain menggunakan sabun dan air. Hand sanitizer biasanya dikemas dalam bentuk gel dan spray dalam ukuran botol yang minim sehingga dapat dengan mudah di bawa kemanapun (Aminah dkk, 2018). Namun, selama masa pandemi ini hand sanitizer menjadi barang langka di pasaran dan mahal. Hal tersebut membuat masyarakat kesulitan mendapatkannya. Kondisi ini pula yang dialami masyarakat Kotalintang, dimana hasil wawancara dengan seorang pedagang di Kotalintang mengatakan bahwa sangat sulit mendapatkan hand sanitizer meskipun sudah mencari di berbagai tempat. Oleh karena itu perlu dilakukan upaya alternatif untuk menghambat dan mencegah infeksi virus corona, salah satu upaya yang dapat dilakukan adalah dengan pelatihan pembuatan hand sanitizer berbasis bahan alami. Bahan alami yang dimaksud adalah dengan memanfaatkan ekstrak daun halban (vitex pinnata linn) dan lidah buaya (aloe vera) yang terdapat di sekitar desa sebagai antimikroba dan pelembut dalam hand sanitizer (Kurnia, 2020).

Daun halban (vitex pinnata linn) merupakan salah satu tanaman yang memiliki kandungan antibakteria yang baik (Mastura, 2017). Penggunaan ektrak daun halban (vitex pinnata linn) dalam pembuatan hand sanitizer berfungsi sebagai pencegah tumbuhnya bakteri dalam hand sanitizer yang telah dibuat selama masa penyimpanan, sehingga hand sanitizer dapat digunakan dalam waktu yang relatif lebih lama. Sedangkan ekstrak lidah buaya (aloe vera) berfungsi sebagai pelembut dan pengental sehingga cairan hand sanitizer mudah diaplikasikan pada kulit. Selain itu lidah buaya (aloe vera) juga berguna untuk melembabkan kulit sehingga dapat mengatasi iritasi yang mungkin ditimbulkan oleh alkohol (Kurnia, 2020).

Adapun tujuan dari pelatihan ini adalah untuk menghasilkan hand sanitizer sebagai cairan pembersih tangan untuk mengantisifasi terninfeksi dari virus Corona dengan memanfaatkan bahan-bahan alami yang terdapat di sekitar desa.

\section{Profil Peserta Pelatihan}

Adapun peserta pelatihan adalah para ibu PKK yang berlatar belakang sebagai Ibu Rumah Tangga dan para pemuda Desa Kota Lintang yang berlatar belakang sebagai pedagang, penjaga took dll. 
Rahmatul Fajri, dkk. Pelatihan Pembuatan Hand Sanitizer (Hanzer) Menggunakan ...

\section{METODE PELAKSANAAN}

\begin{tabular}{lrr}
\multicolumn{3}{c}{ Kegiatan pelatihan dalam rangka } \\
pengabdian & kepada & masyarakat \\
dilaksanakan & dengan & mengikuti \\
tahaptahap sebagai berikut &
\end{tabular}

1. Tahap Sosialisasi dan Persiapan

2. Tahap persiapan dillaksanakan dua minggu dengan kegiatan sebagai berikut;

a. Koordinasi dengan Datok/Kepala Desa melalui pertemuan intens diskusi.

b. Menentukan jadwal pelatihan dengan menyesuaikan dengan waktu peserta pelatihan.

c. Menyiapkan materi pelatihan dan metode yang sesuai sehingga materi mudah disampaikan.

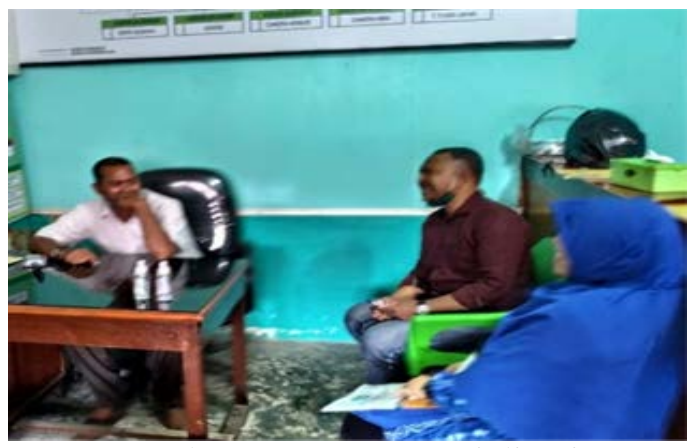

Gambar 1. Suasana Sosialisasi

\section{Tahap Pelaksaan Pelatihan}

Setelah penyampaian materi selanjutnya adalah demonstrasi cara membuat cairan antiseptik hand sanitizer dari bahan alami. Demonstrasi dilakukan oleh tim PKM yang kemudian dipraktek oleh para peserta kegiatan. Setelah melakukan demonstrasi, selanjutnya peserta kegiatan diwajibkan untuk melakukan praktek secara kelompok pada kelompok masing-masing. Selama kegiatan praktek berlangsung, setiap kelompok akan terus dibimbing dan didampingi secara intensif oleh tim PKM.

\section{Pembuatan Hand Sanitizer}

Bahan yang digunakan dalam pembuatan hand sanitizer antara lain adalah alkohol $70 \%$ dapat membunuh bakteri dan virus, alkohol tetap digunakan karena sesuai dengan standar WHO. air bersih digunakan dalam mengekstraksi daun halban dan lidah buaya, daun halban berguna sebagai pengganti hidrogen peroksida yaitu berperan sebagai antibakteria atau dapat menghambat pertumbuhan bakteri dalam cairan hand sanitizer nantinya, dan lidah buaya tidak berperan sebagai pembunuh kuman tapi hanya memberi konsistensi pada alkohol agar lebih mudah untuk diaplikasikan ke kulit, atau dengan kata lain sebagai pelembut dan pengental cairan. Lidah buaya juga berperan untuk melembabkan kulit sehingga dapat mengatasi iritasi yang mungkin ditimbulkan oleh alkohol. Selanjutnya esensial oil sebagai pewangi (Fitri, 2020).

a) Daun halban yang telah diperoleh dicuci dan dipotong dengan ukuran kira-kira $1 \mathrm{~cm}$, selanjutnya dimasukkan ke dalam wadah dan masukkan alkohol secukupnya hingga daun halban tenggelam, biarkan selama 3x24 jam dalam keadaan tertutup. Selanjutnya disaring

b) Lidah buaya yang telah diperoleh dicuci dan dibersihkan dari kulitnya kemudian dihancurkan dengan diblender atau ditumbuk hingga mengeluarkan busa. Selanjutnya, campurkan dengan alkohol, kocok hingga homogen dan saring.

c) Ekstraksi daun halban yang telah diperoleh dicampurkan dengan ektraksi lidah buaya dan diaduk hingga merata atau dikocok, tambahkan essensial oil sebagai pewangi.

d) Cairan yang telah diperoleh dimasukkan ke dalam botol spray 
yang telah disiapkan dan siap digunakan.

\section{Monitoring dan Evaluasi}

Tahap monitoring dilakukan untuk memantau kemajuan dan keberlanjutan dari kegiatan yang dilakukan. Monitoring dilakukan 2 kali, 2 minggu setelah pelaksanaan kegiatan edukasi. Monitoring dilakukan untuk mengetahui tanggapan peserta, keberlanjutan kegiatan dan persentase peningkatan kesadaran terhadap kebersihan tangan.

Evaluasi dilakukan oleh tim pelaksana kegiatan PKM setelah peserta menerima materi dan pelatihan pembuatan cairan hand sanitizer berbasis bahan alami daun halban dan lidah buaya. Adapun kriteria penilaian meliputi pemahaman materi penyuluhan dan penerapan materi yang telah diberikan selama proses kegiatan berlangsung. Evaluasi selanjutnya dilakukan oleh Anggota Komisi Lembaga Pengabdian Kepada Masyarakat guna menilai keberhasilan pelaksanaan kegiatan.

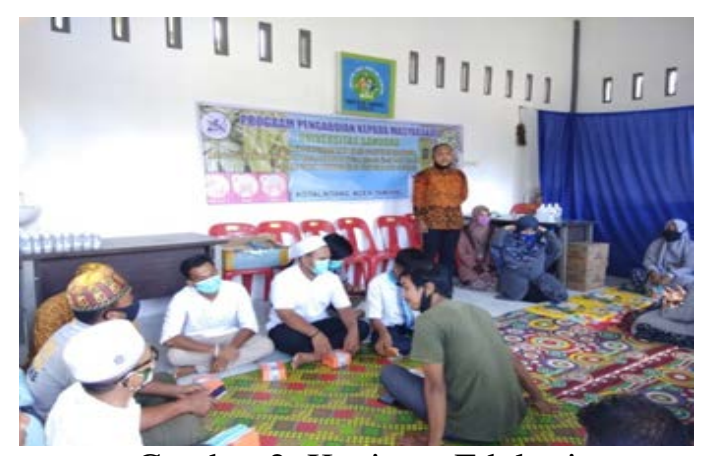

Gambar 2. Kegiatan Edukasi

\section{HASIL DAN PEMBAHASAN}

Berdasarkan hasil sosialisasi yang dilakukan pada tanggal 02 September 2020 di kantor Datok/Kepala Desa kota Lintang Aceh Tamiang. Berdasarkan hasil sosialisasi yang dilakukan menunjukkan bahwa Datok/ kepala Desa menyambut hangat dan antusias yang tinggi terhadap kegiatan yang dilakukan.

Kegiatan pelatihan yang dilakukan pada tanggal 10 September 2020. Kegiatan diawalai dengan pemberian edukasi akan pentingnya menjaga kebersihan tangan di masamasa pandemic saaat ini, serta tim juga memberikan beberapa materi terkait penyebaran virus korona serta bagaimana cara penanggulangannya. Selanjutnya kegiatan dilanjutkan dengan diskusi Tanya jawab mengenai materi serta praktek yang akan dilakukan, hal tersebut menunjukkan bahwa masyarakat Desa Kota Lintang sangat antusias dan semangat dalam menanggapi pelatihan yang diberikan oleh tim Pengabdian Kepada Masyarakat Universitas Samudra. Masyarakat berpendapat bahwa pelatihan yang dilakukan sesuai dengan kebutuhan masyarakat saat ini. Dimana, dalam masa pandemik ini masyarakat sulit untuk memperoleh bahan antiseptik seperti hand sanitizer yang telah menjadi kebutuhan primer masyarakat saat ini.

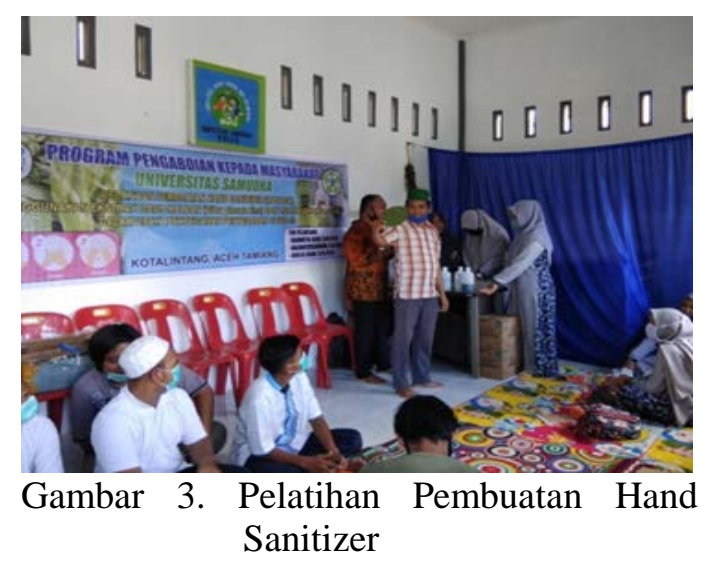

Pelatihan ini dilakukan dengan tujuan untuk meningkatkan kesadaran masyarakat akan pentingnya kebersihan tangan untuk menghindari terpaparnya dari covid-19. Selain itu untuk menghasilkan hand sanitizer sebagai 
cairan pembersih tangan untuk mengantisifasi terninfeksi dari virus Corona dengan memanfaatkan bahanbahan alami yang terdapat di sekitar desa.

Hand sanitizer adalah cairan pembersih tangan yang digunakan sebagai alternatif untuk mencuci tangan selain menggunakan sabun dan air. Hand sanitizer biasanya dikemas dalam bentuk gel dan spray dalam ukuran botol yang minim sehingga dapat dengan mudah di bawa kemanapun (Aminah dkk, 2018). Oleh karena itu perlu dilakukan upaya alternatif untuk menghambat dan mencegah infeksi virus corona, salah satu upaya yang dapat dilakukan adalah dengan pelatihan pembuatan hand sanitizer berbasis bahan alami. Bahan alami yang dimaksud adalah dengan memanfaatkan ekstrak daun halban (vitex pinnata linn) dan lidah buaya (aloe vera) yang terdapat di sekitar desa sebagai antimikroba dan pelembut dalam hand sanitizer.

Daun halban (vitex pinnata linn) merupakan salah satu tanaman yang memiliki kandungan antibakteria yang baik. Penggunaan ektrak daun halban (vitex pinnata linn) dalam pembuatan hand sanitizer berfungsi sebagai pencegah tumbuhnya bakteri dalam hand sanitizer yang telah dibuat selama masa penyimpanan, sehingga hand sanitizer dapat digunakan dalam waktu yang relatif lebih lama (Mastura, 2017). Sedangkan ekstrak lidah buaya (aloe vera) berfungsi sebagai pelembut dan pengental sehingga cairan hand sanitizer mudah diaplikasikan pada kulit. Selain itu lidah buaya (aloe vera) juga berguna untuk melembabkan kulit sehingga dapat mengatasi iritasi yang mungkin ditimbulkan oleh alkohol.

Dengan dilakukan Pelatihan pembuatan hand sanitizer di Desa Kota Lintang ini diharapkan dapat meningkatkan pengetahuan dan kepedulian masyarakat terhadap akan pentingkan kebersihan tangan untuk menjaga terhindar dari virus yang mematikan, selain itu dengan ada adanya kegiatan ini dapat memberikan informasi kepada masyarakat bahwa bahan-bahan alami yang ada di sekitar pekarangan rumah dapat dimanfaatkan sebagai bahan dasar pembuatan hand sanitizer. Berdasarkan hasil wawancara kami dengan beberapa peserta terkait pengetahuan mereka mengenai hand sanitizer berbahan alami, ternyata banyak masyarakat yang tidak tahu bahwa bahan-bahan yang ada disekitar rumah bias dimanfaatkan sebagan bahan pembuatan hand sanitizer, awalnya masyarakat beranggapan bahwa hand sanitizer hanya bias dibuat dengan bahan-bahan kimia saja yang relative harganya sangat mahal. Setelah mengikuti pelatihan masyarakat mulai berencana untuk mencoba membuat sendiri hand sanitizer dengan memanfaatkan tanaman yang ada disekitar, bahkan ada yang ingin menjadikan sebagai peluang bisnis, mengingat di masa-masa pandemic ini hand sanitizer menajdi bahan yang langka dan mahal.

\section{SIMPULAN}

Kesimpulan dari pelaksanaan
program Pengabdian kepada
Masyarakat (PKM) ini yaitu tingginya
partisipasi mitra terhadap program
kegiatan peltihan pelatihan pembuatan
hand sanitizer (hanzer) menggunakan
ekstrak daun halban (vitex pinnata linn)
dan lidah buaya (aloe vera) dalam upaya
pencegahan penyebaran covid-19 di
desa kotalintang kabupaten aceh
tamiang. Diharapkan dengan pelatihan
tersebut masyarakat mampu
menghasilkan hand sanitizer sendiri dan


dapat meningkatkan kesadaran akan pentingnya menjaga kesehatan.

\section{UCAPAN TERIMA KASIH}

Terima kasi kepada Universitas Samudra yang telah memberikan bantuan dana untuk kegiatan pengabdian masyarakat melalui program pengabdian masyarakat Tahun 2020.

\section{DAFTAR PUSTAKA}

Ainil, F. Cara Bikin Hand Sanitizer Sendiri Untuk Cegah Virus Corona. Diakses 26 April 2020.

Aminah, A. Aprilia, B, R. dan Nopitasari. 2018. Kualitas Gel Pembersih Tangan (Handsanitizer) dari Ekstrak Batang Pisang dengan Penambahan Alkohol, Triklosan dan Gliserin yang Berbeda Dosisnya. Jurnal Bioeksperimen Volume 4 No. 2

Dinas kesehatan Pemerintah Provinsi Aceh. 2020. Ayo kita lakukan cuci tangan pakai sabun (CTPS) sebagai salah satu upaya pencegahan covid-19.

Direktorat Jenderal Pencegahan dan Pengendalian Penyakit.. 2020.
Pedoman Pencegahan dan Pengendalian Coronavirus Deasease (Covid-19).

Dwi Hapsari1, Ika Dharmayanti1, Supraptini. Pola Penyakit Ispa Dan Diare Berdasarkan Gambaran Rumah Sehat Di Indonesia Dalam Kurun Waktu Sepuluh Tahun Terakhir. Buletin Penelitian Sistem Kesehatan - Vol. 16 No. 4 Oktober 2013: 363-372

Fardhani, H.L. 2014. Pengaruh Metode Ekstraksi Secara Infundasi Dan Maserasi Daun Asam Jawa (Tamarindus Indica L.) Terhadap Kadar Flavonoid Total. Skripsi. Universitas Gajah Mada.

https://www.media.acehprov.go.id/uplo ads/Aceh_Tamiang.pdf, Aceh Tamiang Dalam Angka 2014.

Kurnia, A. Cara Mudah Membuat Hand Sanitizer Sendiri Rekomendasi WHO. Diakses 20 April 2020.

Kurnia, A. Cara Mudah Membuat Hand Sanitizer Sendiri Rekomendasi WHO. Diakses 20 April 2020.

Yiliana, 2020. Corona Virus Diseases (Covid-19): sebuah Tinjauan Literatur. Fakultas kedokteran Universitas lampung. Wellness and Healthymagazine. 